OPEN ACCESS

Citation: S. Carioli (2020) Neorealism in the work of Gianni Rodari. Reflections 100 years after the birth of the author. Rivista di Storia dell'Educazione 7(1): 129-136. doi: $10.36253 /$ rse-9399

Received: February 1, 2020

Accepted: May 29, 2020

Published: July 6, 2020

Copyright: (C) 2020 S. Carioli. This is an open access, peer-reviewed article published by Firenze University Press (http://www.fupress.com/rse) and distributed under the terms of the Creative Commons Attribution License, which permits unrestricted use, distribution, and reproduction in any medium, provided the original author and source are credited.

Data Availability Statement: All relevant data are within the paper and its Supporting Information files.

Competing Interests: The Author(s) declare(s) no conflict of interest.

Editor: Pietro Causarano, Università di Firenze; Rossella Raimondo. Università di Bologna.

\section{Neorealism in the work of Gianni Rodari. Reflections 100 years after the birth of the author}

\author{
Il neorealismo nell'opera di Gianni Rodari. Riflessioni a 100 \\ anni dalla nascita dell'autore
}

\author{
Stefania CARIOLI \\ Università di Firenze, Italia \\ E-mail: stefania.carioli@unifi.it
}

\begin{abstract}
Within the influence of Gramsci's pedagogical model in the work of Gianni Rodari, this article examines the novel Piccoli vagabondi (Small vagabonds) (19521953), a unicum in the author's production of Grammatica della fantasia (The Grammar of Fantasy), as it is characterized by neorealistic themes and by a communicative style that uses "proletarian" rhetoric, progressive vision and utopian elements. After mentioning the national issue of the non-existence of children's literature (which Gramsci mentions in his essays on popular literature) and the neorealistic traits present in Rodari, the paper enters more directly into the merit of the neorealist novel, which presents itself as a document of the pedagogical effort (even contradictory) made by the Partito Comunista Italiano (Italian Communist Party) in the political climate of the "cold war" and as a testimony to the origin of the author's search to reconcile realism with fantasy, dream and invention.
\end{abstract}

Keywords. Gianni Rodari, gramscian pedagogical model, Neorealism genre, children's literature.
Riassunto. A partire dall'influenza del modello pedagogico di Antonio Gramsci nellopera di Gianni Rodari, questo articolo esamina il romanzo Piccoli vagabondi (1952-1953), un unicum nella produzione dell'autore di Grammatica della fantasia, poiché caratterizzato da temi neorealistici e da uno stile comunicativo che utilizza retorica "proletaria", elementi utopici e una visione progressiva. Dopo aver menzionato la questione nazionale della non esistenza della letteratura per l'infanzia (su cui Gramsci si esprime nei suoi saggi sulla "letteratura popolare") e aver enucleato i tratti neorealistici presenti in Rodari, il contributo entra più direttamente nel merito di Piccoli vagabondi, che si presenta, sia come un documento dello sforzo pedagogico (anche contraddittorio) compiuto dal Partito Comunista Italiano nel clima politico della "guerra fredda", sia come testimonianza dell'origine della ricerca di Rodari volta a conciliare il realismo con la fantasia, il sogno e l'invenzione.

Parole chiave. Gianni Rodari, modello pedagogico gramsciano, genere Neorealismo, letteratura per l'infanzia. 


\section{BETWEEN NEOREALISM AND SURREALISM}

Gianni Rodari (1920-1980) is known and appreciated above all as an author of fantastical narratives, invented ${ }^{1}$ stories told to children "partly out of sympathy for them, partly out of a desire to play, stories without the least reference to reality or to good common sense» (Rodari 1993, 1), in which «reality erupts into the surrealistic exercise» (Rodari 1993, 7) to stimulate the children's imagination as a means to understand reality from another point of view. However, in order to understand the complexity of the work of one of the greatest Italian children's writers in the twentieth century (Zipes 1993), it is necessary to take into consideration the neorealist literary mode of his work, and in particular, Piccoli vagabondi (Small vagabonds) (1952-1953), a unicum in the work of this author (Allasia 2018), an «exceptional case» (Detti and Martinez 2002, 165), in which he inserted many traits of the impetuous democratic and popular movement of the immediate Second post-War period (Argilli 1982, 48), called "neorealism". In terms of literary mode this neorealistic novel is undoubtedly very far from the magic realism and surrealist techniques, which Rodari had constantly experimented with (Zipes 2014). We find this, for example, in a «bizarre fairy-tale novel» (Zipes 2014, 424), like There was twice Baron Lamberto, that is, the mysteries of the island of San Giulio (C'era due volte il barone Lamberto, ovvero, I misteri dell'isola di San Giulio) (1978). Just as it is far from the «art of making people laugh» (Detti and Martinez 2002) it is typical of Rodari. Piccoli vagabondi portrays the childhood discomfort of the postwar Reconstruction in Italy. It educates children to give a personal contribution to a collective life, which is according to the ideology of the communist party. For these reasons, the fantastic mode is completely excluded from it. Moreover, the very fact that this novel has remained unique in the opera of Rodari testifies the choice to express his political and pedagogical commitment through the imagination and the invention of "every possible use of words", "not because everyone should be an artist but because no one should be a slave» (Rodari 1993, 4).

Many reasons have meant that the novel Piccoli vagabondi has remained in the shadows more than any other of Rodari's other works. These reasons were most likely also related to leftist ideology (which in Piccoli

\footnotetext{
${ }^{1}$ Translation note: the term "invented" is used here instead of "created", because it is closer to the term used in the Italian title Grammatica della fantasia. Introduzione all'arte di inventare storie. The same choice has been made by Jack David Zipes in the translation of the Grammatica della fantasia into English: The Grammar of Fantasy: An Introduction to the Art of Inventing Stories (1993).
}

vagabondi shines in a particularly evident way, as confirmed by the presence of ideological symbols, such as the crossed sickle and hammer) highlighted by Jack Zipes, in The Incomprehensible Gianni Rodari:

\begin{abstract}
Admittedly, Rodari is difficult to translate, and only a few of his books have been translated. But I do not believe that the reluctance of American and British publishers to translate $^{2}$ Rodari is entirely connected to the complexity of his works. It has more to do with his socialist ideology, his unique Italian humor, and his overt sentimentalism, which can be difficult to adapt and communicate, especially in the realm of children's literature. Here, too, there is a problem because Rodari never wrote entirely for children; rather, he wrote on their behalf and constantly undermined the position and perspective of adults through silly nonsense and fervent political beliefs (Zipes 2014, 424).
\end{abstract}

Therefore, there are many good reasons to analyze neorealism in the works of Gianni Rodari, 100 years after his birth. In addition to the importance of the novel Piccoli vagabondi as a historical source of the sociopolitical climate in which it was written, there are more pure pedagogical reasons. In fact, this neorealist novel was at the birth of the idea of Gramscian origin (Welton 1982). It was of particular interest, according to which the education of children of subordinate classes had to be considered an essential element in a democratic society. In time, this process led Rodari from telling tragic stories that could have been real, to the awareness that, "generally speaking, we laugh too little in our schools» (Martinez 2002, 165) and that «the idea that educating the mind ought to be something gloomy is among the most difficult notions to combat» (Martinez 2002, 165).

\section{THE NATIONAL "QUISTIONE"3 (ISSUE) OF THE NON- EXISTENCE OF CHILDREN’S LITERATURE}

At a very young age Rodari found himself teaching Italian to children in the home of German Jews. Then for a short time he became a primary school teacher (Rodari 1973). At the end of the war, he actively participated in the moral development of the country, and in this effort, Rodari was significantly influenced by the Gramscian pedagogical model (Cambi 1985; De Luca 2017; Genovesi 2017), of which he observed these fundamental aspects: the impossibility of isolating literary

\footnotetext{
${ }^{2}$ This is not the appropriate place to enter into the merits of the issues related to the English translation of Rodari's works, for example, to the "different foreignising and domesticating strategies» (Alborghetti 2015) for which I refer to specific works such as: Alborghetti 2015.

${ }^{3}$ Popular variant of the term "questione", used by Gramsci to indicate a situation that constitutes a problem.
} 
interest from social interest and an intellectual and moral renewal for a culture which should never evade reality. According to the Gramscian model, the new intellectual, the writer, had to perform a national educational function, elaborating popular sentiment: he no longer had to live separately from the people, but deeply embedded in them (Gramsci 1948/1996):

The intellectuals do not feel tied to the Italian people, they do not know or sense their needs, aspirations and feelings. In relation to the people, they are somewhat detached, without foundation or caste and whitout a connection to organic functions of the people themselves (Gramsci 1950, 105-106).

According to Antonio Gramsci, to achieve a revolution of the people, an intellectual and moral reform should have taken place, even if not exclusively, in the «letteratura narrativa» (narrative literature) (Gramsci 1950). In the context of the lack of national literature, Gramsci stressed the issue of the non-existence of children's literature. In his essays on popular literature, he had drawn up "the 'catalogue' of the most important questions to be examined and analysed, which ranged from the non-'popularity' of Italian literature, [...] to the non-existence of Italian children's literature. The concept of egemonia (hegemony) brought these issues down to the common denominator of the struggle for a 'new culture'» (Pohn-Lauggas 2019, 299); «un altro elemento è quello della non esistenza di 'romanzi d'appendice' e di letteratura per l'infanzia (romanzi d'avventura, scientifici, polizieschi, ecc.) e del fatto che tali libri sono introdotti dall'estero» (Gramsci 1932-1935, 1669) ${ }^{4}$. Rodari worked on the project of new children's literature in the 1950's with hard political, civil and pedagogical work. In the Second post-War he lead Italian children's literature into a new direction, which cared about the needs of the people (Gramsci 1950):

In the last century, newspapers and children's books were written for the elite, namely bourgeois families. Today they appeal to a huge audience. For this reason, their commercial approach prevailed the educational principles culture. What can help us cope with this situation? Essentially the birth of new literature for children, that is also capable with an organizational means of conducting an effective struggle (Rodari 1952a, 52).

The main project in this particular historical moment was to guide Italy in its difficult transition from the oppression of rigid fascist ways (Fincardi 2013) to ideas of freedom based on the secular values of the

${ }^{4}$ Available at https://tinyurl.com/rxe38k6. Accessed January 28, 2020).
Costituzione italiana (The Constitution of the Italian Republic) (1 January 1948). Rodari collaborated on this project as a representative to the educational and ideological effort made by the Partito comunista italiano (Pci). The resounding defeat that the Italian Left party suffered on April 18, 1948 had led the Pci to commit itself to contrasting the Christian hegemony in the field of education, with the aim to prevent children from becoming easy tools of the bourgeoisie (Odescalchi 1997-98, 7). However, Rodari was not a mere executor of his ideological choice: he was also critical and often he was in explicit contrast with the leadership of the Pci and with its contradictions (Carioli 2019).

The intent to animate the project of new children's literature led Rodari to conceive and direct (from 1950 to 1953) the Pioniere (Pioneer), an illustrated children's periodical that became the centerpiece of youth editorial production, influenced by the $\mathrm{Pci}^{5}$, and at the center of its pedagogical commitment. The Pioniere was the first children's periodical of the Italian democratic movement (Rinaldi 1960, 82), which inspired its content to the Risorgimento ideals and to the partisan struggle; it was the only one to disclose, among children, the most advanced educational principles and progressive world of the worker and of our Republican Constitution. Rodari used themes such as the history of African Americans and racism, the Italian and European partisan struggle and scientific achievements, in the belief that the values of children's literature was not only to be understood as a stimulus for the imagination, but to also make the reader aware of his/her critical conscience (Rinaldi 1960, 82). In this children's periodical, the neorealistic novel Piccoli vagabondi was published for the first time in 32 episodes, from 21 December 1952 to 5 July 1953; it was subsequently republished in a single volume by the Editori Riuniti in 1981, edited by Marcello Argilli, another children's writer who was a collaborator of Rodari and Dina Rinaldi with the editorial staff of the Pioniere.

\section{CHARACTERISTICS IN COMMON BETWEEN CHILDREN'S LITERATURE OF RODARI (IN PIONIERE) AND THE NEOREALISM}

Piccoli vagabondi is a neorealistic novel, explicitly aligned with motives of many Second post-War Italian narratives. It privileged social engagement, political declaration and testimony narration (Boero 1992,

\footnotetext{
${ }^{5}$ In the article "La nostra stampa", in Il Costruttore, n. 2, febbraio 1954, Enrico Berlinguer explicitly speaks of the Pioniere as one of the publications of the communist youth movement.
} 
127). Although this novel is described as an exception in Rodari's work (Marchioro 1997-1998), it is also true that the early children's literature of Rodari had many characteristics in common with the tout-court neorealist literature.

Anti-fascism. Primarily anti-fascism had unified the work of neorealist authors since the beginning of neorealism (Asor Rosa 1974). After the Second World War, anti-fascism became a dominant theme among the new trends in children's literature. Rodari underlined the deep and lasting influence of the Resistance and the ideal of the democratic struggle. In Italy, as he stated, this push matured the relationship between writers and children readers:

The ideal drive of the democratic struggle in Italy has changed the relationship between children's writers and their audience, to bring into their dialogue themes that were once excluded from children's books: the theme of peace and war, that of freedom and problems in today's world... Other themes in children's books: the south, emigration, knowledge and understanding between people and social justice (Rodari 1969, 118).

These new ideals circulated in neorealist novels, fantastical novels, short stories and sometimes even in the most traditional form of the fairy tale:

A significant group of authors have inserted these themes in their works, and I am not speaking only of the few who have given direct narratives of the events of the Resistance: I am speaking of the new spirit, of the new ideals which circulate in novels, tales, adventures and sometimes even in the most traditional forms of the fairy tale (Rodari 1969, 118).

The engagement to social transformation. Another common trait between neorealist writers and Rodari is the concept of engaged literature. For the neorealists, the crux of the cultural question was not so much the renewal of art and literature, but the social transformation. In this sense, neorealist literature possessed the national popular traits hoped for by Gramsci, that is, a literature that had to respond to the needs of the people. The people had to to be able to reflect and see themselves, to find their feelings, tastes and expressed tendencies. In essence, the neo-realists' decision to write was motivated more by human, practical and ethical-political reasons rather than those of artistic- cultural and aesthetic reasons (Borsato 1984/85). Rodari made social use of children's literature, as an educational medium to pursue certain socio-cultural objectives.

Realism. "Realism", in other words is to narrate the most painful and tragic reality of the postwar Reconstruction in Italy. It is a trait that unites neorealist litera- ture and neorealist children's literature. The central topic is childhood discomfort, the weakest and most subordinate part of society, which were seen in the following forms: the painful issue of children who were hit by the bombing or who were injured by unexploded bombes that were still scattered throughout the city and countryside; the widespread phenomenon of "street kids": vagabonds, beggars, small thieves who were most often exploited by unscrupulous adults, children employed in occasional jobs, accordion players who seemed to bring back the urban environment in the 19th century, with the addition of the desolation of dilapidated houses (Montino 2012); the school, which did not apply the entire school-age population, was therefore still a right for many children to conquer.

In this way, the neorealist children's literature managed to tell the complexity of those years and to restore the sense of the period in our history in which the struggle for survival sacrificed children.

Neorealism literary mode as a political choice. To fully understand the narrative adopted by Rodari in writing the novel Piccoli vagabondi, it is essential to analyze the political and cultural climate of the marshallized Italy of the early 1950's. The cold war between the US and the USSR and the bitter military and ideological and political opposition contrasted pro-American and pro-Soviet parties. In the perspective of the central committee of the Pci, the evasive fantastical literary mode became representative of the American capitalist and individualist culture, whose main objective was to bring children out of the reality, in an imaginative, false and unreal world to distract them from the reality in which they lived and to distance them from the struggle for a better world, for work, freedom and peace (Musu' ${ }^{6}$ 1950). Therefore, in this context, the evasive fantastical literary mode identified a type of press, American or Catholic, that wanted to let children escape from reality. On the contrary, the objective of the Pci was to not lead children to escape from reality, showing them that «against the unreal, sick world, against resignation and individualism, young Democrats struggle. They were convinced that an existence inspired by an idea or a life full of social concerns, all oriented towards a fixed purpose, was the best and the most interesting of the existences that could be conceived (Kalinin: Communist Education)» (Musu 1950). The main representatives of the evasive fantastical literary mode

\footnotetext{
${ }^{6}$ Marisa Musu was a partisan and, after the war, she collaborated with Enrico Berlinguer in the direction of the Italian Communist Youth Federation (FGCI). In 1976, she was the founder, together with Gianni Rodari, of "Coordinamento genitori democratici" (https:// tinyurl.com/yb8jwncn), a non-profit organization founded on the wave of movements of participation and democratic renewal of traditional institutions.
} 
were comics, which several political leaders like Palmiro Togliatti ${ }^{7}$ and Nilde Jotti lashed out at. Rodari expressed a very different opinion concerning comics (Rodari 1952a), defending the possibility of making comics different from the American ones, with different form, content, spirit and intentions, because "whoever wants to talk to children must take into account the language to which they are accustomed» (Rodari 1952a, 51). Rodari effectively took his readers on a journey towards a new "engaged" form of fantasy via his serious neorealist short stories like Piccoli vagabondi. He found a way to merge the democratic ideologies of the Pci with the fantastic mode. He was convinced that fantasy is a means to understand reality, rather than a form to escape from it, and it is a rediscovery and representation of reality in a new form. Then he sought to reconcile «the two opposing positions» (Hunt 2004, 1106): "on one side, that of realists, who set up models to follow, such as working-class heroes' sons, and on the other, that of those who were more sensitive to the popular and cultural heritage, who favored fantasy, dream and invention» (Hunt 2004, 1106). In the search for a new children's literature, Piccoli vagabondi - as well as other novels published in the Pioniere, such as, Mezza-Lira. Scugnizzo di Spaccanapoli by Franco Prattico, published in episodes in 1957, and the partisan short stories, such as, Pucitto by Dina Bertoni Jovine and Pollicino e Top-Top per la libertà by Arturo Oreggia, or the series of partisan tales (1953) by Luisa Monti Sturani - represents the origins of the path, in which the neorealism literary mode is evident. As pointed out by Dina Bertoni Jovine, the realism literary mode had developed in a distinct form compared to the evasive fantastical literary mode between the second half of the 19th century and the first decades of the 20th century: the realism literary mode offered (with the children's literature of Luigi Capuana [1839-1915], Giuseppe Ernesto Nuccio [1874-1933], Olimpia De Gaspari De Benedetti and Alfredo Bajocco [1882-1965]) the examination of those aspects of the life of children of people closely connected with to the social question: suffering, exploitation, sale of children, the consequences of the excessive misery of the proletariat; moreover, the nineteenth-century tradition of children's literature had the theme of "vicissitudes of the young wandering brothers" at heart, in which the novel Piccoli vagabondi (Boero and De Luca, 1995/2016) is built. The evasive fantastical literary mode conversely led the children out of all social problems, solving morality in environments with imaginary characters (Bertoni Jovine 1952, 502) ${ }^{8}$.

\footnotetext{
${ }^{7}$ Palmiro Togliatti was a founding member of the Pci and was Secretary General from 1945 until his death in 1964.

${ }^{8}$ Bertoni Jovine said that these two modes (the current of the adventurous genre and the current of the realistic genre) developed from
}

\section{PICCOLI VAGABONDI}

Although Piccoli vagabondi is a neorealistic novel, it stands out from other neorealist works, such as the first novel of Italo Calvino', Il sentiero dei nidi di ragno (1947). In his novel, Calvino offers a complex and ironic representation of the anti-Fascist armed Resistance in Italy (Re 1991), revisited through the eyes of a child, from a perspective that gives the narrative a masterful fairytale style, even though the events contain historical dramatic implications (Beseghi 2015), in Piccoli vagabondi Rodari does not use the weapons of irony, irreverence and imagination that he would later use. Calvino himself, in the introduction of C'era due volte il barone Lamberto, underlined that Gianni Rodari gave free rein to his imagination, with therefore inspired panache and gleeful lighthearthedness. The true story, as Rodari defines in Piccoli vagabondi, is full of events belonging to the chronicles of the times, such as the catastrophic flooding of the Polesine of 1951 and the struggles of the farmers to obtain land. These events enter the narration and life of the protagonists and become the background on which to base examples of the difficult conditions of the lower classes, class differences, altruistic behaviours, honesty as true freedom.

It is also a deliberately distant and distinct stylistic choice from that of the style of great adventure novels. Rodari stated this quite clearly in the beginning of chapter XIII of Piccoli vagabondi, in which he spoke directly to his young readers:

Dear children ${ }^{10}$, the difference between this story and a great adventure novel is that everything here is true from the first word to the last In this story I did not want to tell you about incredible adventures, but how Anna, Francesco and Domenico have gained their strength, as they day by day have became adults. Pirate Adventures are more colourful and fascinating, of course: but the adventure of becoming a man is more beautiful, because it is more true (Rodari 1953a, 3).

Collodi, De Amicis and Baccini. But what about Pinocchio? In a way Rodari did something similar to Collodi. Just as Collodi created a form of literature that was new and which was termed «domestic fantasy" (Myers 2016), Rodari created a new form of children's literature, because he managed to merge the two modes (realistic and fantastic). Rodari had a lot of respect for Collodi, no doubt because of this and in many ways his work builds on this merging of the real and the fantastic that Collodi began in the 1880s.

${ }^{9}$ Rodari was often been compared to Calvino, in both their different and their original expressive frameworks, and their stylistic, graphic and content of children's literature in the post-war period (Beseghi 2015).

${ }^{10}$ This quote reminds a bit of how Collodi subverts the fairytale in the opening of Pinocchio by saying that his will not be a story about kings and queens but about a simple piece of firewood. 


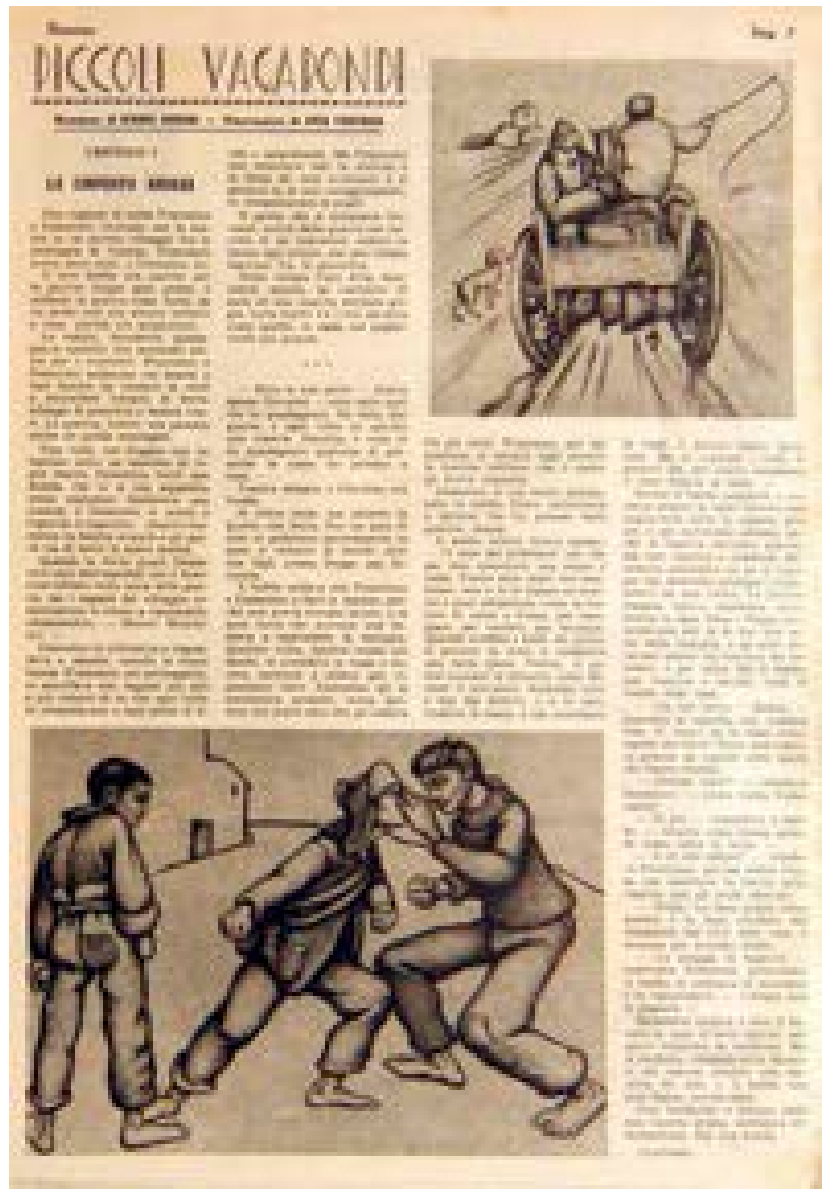

Fig. 1. First episode of Piccoli vagabondi (Rodari 1952b, 7) with illustrations by Rita Thermes (source: http://www.ilpioniere.org).

The time set of Piccoli vagabondi was that of the postwar Reconstruction in Italy, during which time, Rodari actually wrote this neorealist novel. He had a dual purpose explicitely aimed to denounce the problems and living conditions of the lower classes and to create a class consciousness in children through their full participation concerning problems of adults. The little wanderers - orphans, like many children at the end of the war - are Anna, perhaps a ten year old girl (Rodari 1953b, 7), Domenico six years old, who touches the hearts of the people because is right hand had been mutilated by a bomb (Rodari 1952b, 7) and his brother Francesco, nine years old. The theme of orphanage and that of poverty were among the main themes that belong to nineteenthcentury realism, which Rodari followed in this novel. The three orphans embarked on a long journey (the journey as a topos of children's literature, was a metaphor for both individual training and transition from one condition to another) they are taken by caravan from their poor village in the mountains of Cassino (Rodari 1952b,
7), where they lived. They crossed the peninsula: from Rome to the Marches, to Ferrara and to Milan. Francesco and Domenico were sold "for rent" by their mother Benedetta, who was widowed and illiterate. She was forced into making this decision as a result of the two deceitful evil thieves, Don Vincenzo and Pio l'Albino, who took advantage of her poverty. Rodari managed to describe the social scourge of poverty and illiteracy with realism and delicacy, returning to it several times throughout the story, from various perspectives. In the II chapter, entitled L'uomo con la carta (The man with the paper), he recounts the episode of Benedetta, who was forced to sign a paper, which she could not understand (- I can't read - murmured Benedetta with a voice that trembled... but she had to resign herself to letting go of her two boys. She could not let her four children die of hunger [Rodari 1952b, 7]).

Again Rodari mentioned the issue of illiteracy at the end of the IV chapter, in which he described the episode of Francesco who, while watching a procession of peasants who were protesting about land rights, sees a sign where there are black marks next to each other. For him they are all the same (Rodari 1953b, 7). Rodari resumes this topic again at the end of the X chapter and then in the XI chapter, where he tells of the meeting of the three little wanderers with a school, a teacher and her pupils. An ideal school, which recalls in some respects the Nineteenth-century images of many educational readings (Montino 2012), and in Rodari's novel the school is an instrument of liberation from illiteracy and of social ascension: The building, white and clean, stood in the middle of a courtyard where about thirty children played loudly. The three little wanderers stopped to look inside the gate, eyes wide. Almost immediately while the children were playing, two, then three, five broke away and came towards them, a little uncertain and embarrassed.

- They are gypsies, cried a little girl, don't come near! (Rodari 1953d, 3).

- Good morning - said the teacher with a slight smile.

- Are you from far away? The three did not respond, but Anna risked a smile too. [...]

- They are not gypsies, - explained the teacher to her children - they are children, who come from the South, perhaps their country was destroyed by the war.

[...]

- I've been to school - said Anna. - I did the first one. They don't. They never went there. - And can you still read? Asked the teacher. - I think so. At home I have all the notebooks and the reading books. I liked going to school. But then I no longer had shoes and an apron, and I had to help my aunt with small children, and so I never went back. Some of the school children laughed, pointing to Francesco and Domenico: 
- They never went to school, they can't read and write, they are really two donkeys! The teacher shook her head.

- It's not their fault. If they could have gone there, they would have learned better than you. Isn't that right? And he leaned towards Francesco, who nodded yes.

When Francesco had finished telling his story ..., he saw with amazement that some school children had tears in their eyes (Rodari 1953e, 3).

In chapter XIV, Rodari returned to the importance of reading, referring to the books given by the lady of Ferrara as a small treasure. Here he also described the episode of the story of the beautiful things and the fairies that a lady had given to the three children, and the pleasure that this had given them, even if they did not understand half of what she was telling them (Rodari 1953f, 3). The epilogue of the novel returned to the purely political and ideological theme: - Francesco had a big dream to grow up fast and one day lead the poor peasants of his country to conquer the land so that they could work on the land, farming. He already sees the flag that will wave one day and the crossed sickle and hammer, embroidered in gold on the red fabric: it is the sign of his hope.

Francesco knows that one day, that sign will mean that life will be happy for everyone and nobody will have to suffer, sell their children or suffer bullying and injustice (Rodari 1953g, 3). At the end of Piccoli vagabondi, Francesco is no longer a poor frightened boy: he is already a man who knows what he wants and knows what he will live for. He is already a soldier of labour and knows that one day the victory will be his (Rodari 1953g, 3).

Rodari therefore chooses to end the novel projecting on Francesco an element of trust towards the new generations and their abilities to renew reality for a fairer world, with a utopian element that will continue to distinguish all of his works.

\section{REFERENCES}

Alborghetti, Claudia. 2015. "Images and voices of Gianni Rodari in English translation." PhD diss., University Cattolica del Sacro Cuore. http://hdl.handle. net/10280/10791. Accessed: April 2, 2020.

Allasia, Clara. 2018. "Piccoli vagabondi e Pinocchi di latta: infanzia e povertà nelle pagine del 'Pioniere."' In Infanzia e povertà Storie e narrazioni nell'Italia del dopoguerra (1945-1950), edited by Allasia Clara, Maida Bruno, and Prono Franco, 131-144. Avellino: Edizioni Sinestesie. https://ita.calameo.com/ read/005864328a18e34a96df5 Accessed: January 25, 2020.
Argilli, Marcello. 1982. "Gli inizi della pubblicistica e della letteratura di sinistra per l'infanzia." LG Argomenti 1-2: 3,4 .

Argilli, Marcello. 1990. Gianni Rodari. Una biografia. Torino: Einaudi.

Asor Rosa, Alberto. 1974. Storia ed antologia della letteratura italiana vol. XXII: Letà dell'antifascismo e della resistenza. Alberto Abruzzese (ed.). Firenze: La Nuova Italia.

Berlinguer, Enrico. 1954. "La nostra stampa." Il Costruttore 2.

Bertoni Jovine, Dina. 1952. "La stampa per il popolo dopo l'Unità." Belfagor, 7-5: 489-508. www.jstor.org/ stable/26068759. Accessed: April 8, 2020.

Bertoni Jovine, Dina. 1954. "Pucitto." Pioniere. 4 maggio: 4.

Beseghi, Emma. 2015. "Traces of History in children's tales and narrations." Ricerche di Pedagogia e Didattica. Journal of Theories and Research in Education, 10: 81-94.

Boero, Pino, De Luca, Carmine. 2016. La letteratura per l'infanzia. $1^{\text {a }}$ ed. digitale. Roma-Bari: Laterza.

Boero, Pino. 1992. Una storia, tante storie: guida allopera di Gianni Rodari. Torino: Einaudi.

Borsato, Sergio. 1985. "Uno scrittore contemporaneo per ragazzi: Marcello Argilli." Thesis, University of Padua.

Cambi, Franco. 1985. Collodi, De Amicis, Rodari: tre immagini d'infanzia. Bari: Dedalo.

Carioli, Stefania. 2019. "Racconti e giornali illustrati per l'infanzia d'ispirazione marxista nell'Italia del secondo dopoguerra. Tra esigenze pedagogiche e istanze politiche." "SPES" Rivista della Società di Politica, Educazione e Storia, Suppl. di "Ricerche Pedagogiche" 10: 1-19. https://tinyurl.com/ycqt72pr. Accessed: April 2, 2020).

Corrado, Rosa. 2008. Antonio Gramsci: teorico della traduzione e scrittore per l'infanzia: un contributo allo sviluppo della fantasia dei bambini e alla formazione dei giovani. Roma: Aracne.

De Luca, Carmine, ed. 2017. Gianni Rodari. Il cane di Magonza. Torino: Giulio Einaudi Editore, ET Scrittori.

Detti Ermanno, Ronald L. Martinez. 2002. "The difficult art of making people laugh: Comic children's literature in Italy." The Lion and the Unicorn 26: 150-168.

Fincardi, Marco. 2013. "Pagine d'orientamento per pionieri e falchetti." In Falce e fumetto. Storia della stampa periodica socialista e comunista per l'infanzia in Italia (1893-1965), edited by Juri Meda, 175-203. Firenze: Nerbini.

Genovesi, Giovanni. 2017. "Il 'mio' Gramsci su educazione e scuola." SPES Rivista della Società di Politica, Educazione e Storia, Suppl. di "Ricerche Pedagogi- 
che” 6: 3-40. https://tinyurl.com/y8gx9foo Accessed: 9 April, 2020.

Gramsci, Antonio. 1932-1935. Quaderno 14 (I). In Quaderni del carcere, edited by Valentino Gerratana. Volume terzo Quaderni 12-29. Torino: Giulio Einaudi Editore.

Gramsci, Antonio. 1948/1996. Gli intellettuali e l'organizzazione della cultura, edited by Valentino Gerratana. $3^{\text {a }}$ ed. Roma: Editori riuniti. https://tinyurl.com/ yafocx6t Accessed: January 28, 2020.

Gramsci, Antonio. 1950/1966. Letteratura e vita nazionale. $6^{\mathrm{a}}$ ed. Torino: Giulio Einaudi Editore. https:// tinyurl.com/y94jcrwp. Accessed: January 28, 2020.

Hunt, Peter, ed. 2004. International Companion Encyclopedia of Children's Literature. NY: Routledge.

Marchioro, Michela. Dicembre 1997 - Febbraio 1998. “Il Pioniere', settimanale di tutti i ragazzi d'Italia." In L'Almanacco. Rassegna di studi storici e di ricerche sulla società contemporanea. Istituto per la storia del movimento operaio e socialista di Reggio Emilia "P. Marani”, 29/30. Reggio Emilia: Edizioni La Nuova Tipolito.

Montino, Davide. 2012. "Società, infanzia e narrazioni realistiche nella letteratura giovanile dell'Italia del secondo dopoguerra (1946-1962)." History of Education \& Children's Literature VII: 2: 287-317.

Musu, Marisa. 1950. "Discutiamo sui fumetti." Gioventù Nuova, 4-aprile. https://tinyurl.com/ycf4rd3m. Accessed: April 5, 2020.

Myers, Lindsay. 2016. Un fantasy tutto italiano: le declinazioni del fantastico nella letteratura italiana per l'infanzia dall'Unità al XXI secolo. Pisa: Edizioni ETS.

Odescalchi, Nando. Dicembre 1997 - Febbraio 1998. "Presentazione." In L'Almanacco. Rassegna di studi storici e di ricerche sulla società contemporanea. Istituto per la storia del movimento operaio e socialista di Reggio Emilia “P. Marani”, 29/30. Reggio Emilia: Edizioni La Nuova Tipolito.

Oreggia, Arturo. 1956. "Pollicino e Top-Top per la libertà." Pioniere 1:11.

Pohn-Lauggas, Ingo. 2019. "Past and Present: Popular Literature.” Revisiting Gramscis Notebooks 297-311.

Prattico, Franco. 1957. "Mezza-Lira. Scugnizzo di Spaccanapoli." Pioniere.

Rinaldi, Dina. 1960. "La stampa periodica per ragazzi e i suoi temi." In La letteratura per l'infanzia nel mondo moderno, Atti del Convegno Italo-Sovietico, Torino, 12-13 marzo 1960. Roma: Quaderni di Rassegna Sovietica.

Rodari, Gianni, and Jack Zipes. 2009. "The War of the Bells.” Marvels \& Tales 23: 91-97. www.jstor.org/ stable/41388903 Accessed: 9 April, 2020.
Rodari, Gianni, and Carmine De Luca, ed. 1992. Scuola di fantasia. Roma: Editori Riuniti.

Rodari, Gianni, and Francesco Altan. 1978. C'era due volte il barone Lamberto, ovvero, I misteri dell'isola di San Giulio. Torino: Einaudi.

Rodari, Gianni. 1951. "Il 'Pioniere' e la stampa per ragazzi." La Repubblica dei ragazzi 7-8. Rodari, Gianni. 1952a. "La questione dei fumetti. Lettera al direttore." Rinascita 1: 51.

Rodari, Gianni. 1952b. "Piccoli vagabondi." Pioniere 50-21 dicembre:7. Rodari, Gianni. 1953a. "Piccoli vagabondi." Pioniere 11-15 marzo: 3.

Rodari, Gianni. 1953b. "Piccoli vagabondi." Pioniere 1-4 gennaio: 7 .

Rodari, Gianni. 1953c. "Piccoli vagabondi." Pioniere 2-11 gennaio: 7 .

Rodari, Gianni. 1953d. "Piccoli vagabondi." Pioniere 8-22 febbraio: 3 .

Rodari, Gianni. 1953e. "Piccoli vagabondi." Pioniere 9-1 marzo: 3 .

Rodari, Gianni. 1953f. "Piccoli vagabondi.” Pioniere 12-22 marzo: 3 .

Rodari, Gianni. 1953g. "Piccoli vagabondi." Pioniere 27-5 luglio: 3.

Rodari, Gianni. 1969. "La letteratura infantile oggi." Scuola e città 3 .

Rodari, Gianni. 1973. Grammatica della fantasia. Introduzione all'arte di inventare storie. Torino: Piccola Biblioteca Einaudi.

Rodari, Gianni. 1981/2010. Piccoli vagabondi. Torino: Einaudi Ragazzi.

Rodari, Gianni. 1993. The Grammar of Fantasy, An Introduction to the Art of Inventing Stories. Translated by Jack Zipes. New York: Teachers and Writers Collaborative.

Santamaita, Saverio. 2010. Storia della scuola. Dalla scuola al sistema formativo. Milano: Bruno Mondadori.

Welton, Michael. 1982. "Gramsci's Contribution To The Analysis of Public Education Knowledge." The Journal of Educational Thought (JET)/Revue De La Pensée Éducative 3: 140-149. https://www.jstor.org/stable/23768314. Accessed: 11 Apr. 2020.

Zipes, Jack. 2014. "The Incomprehensible Gianni Rodari." Marvels \& Tales 28-2: 424-432.

\section{WEBSITE}

Pioniere (documents digitized by the Gramsci Emilia Romagna Bologna Foundation Archive) http://www. ilpioniere.org/ Accessed January 31, 2020. 